\title{
A busca inglesa pelo curso do Rio Níger: do problema geográfico à possessão potencial
}

The British search for the course of the Niger River: from a geographical problem to

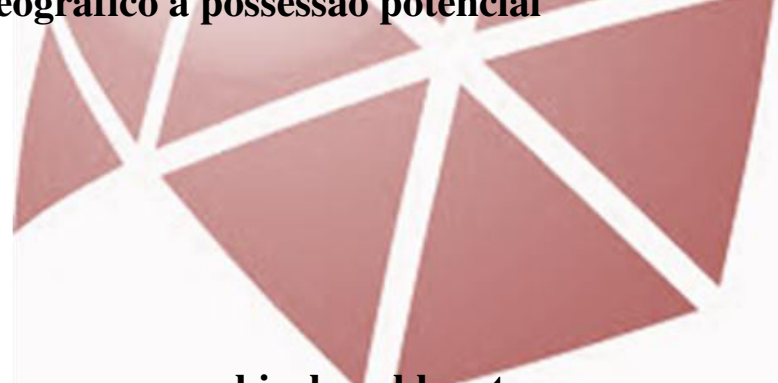
potential possession

\begin{abstract}
Alexsander Lemos de Almeida GEBARA*
Resumo: O artigo analisa o corpo de textos produzidos por expedições inglesas na região do rio Niger entre primeira viagem de Mungo Park (1795) e a expedição oficial britânica de 1841 procurando notar as semelhanças e diferenças nas representações ao longo do tempo. O período em questão apresenta grandes transformações no contexto atlântico, incluindo o final do tráfico de escravos pela Inglaterra, e marca também uma alteração no equilíbrio das forças na costa e no interior da África Ocidental. Desta forma, o trabalho procura mostrar como as ideias inglesas sobre escravidão e tráfico de escravos interferem nas dinâmicas de representação e nas práticas diplomáticas europeias para com as sociedades próximas ao curso do rio Niger. Finalmente, o artigo também aponta para a forma como as preocupações quase exclusivamente geográficas das primeiras viagens paulatinamente adquiriram o caráter intervencionista de um discurso de posse ao mesmo tempo em que as novas condições materiais e técnicas desequilibravam as relações de força em favor da Inglaterra.
\end{abstract}

Palavras-chave: ingleses, Rio Níger, escravidão, diplomacia.

Abstract: This paper analyzes a body of texts written during British expeditions in the region of
the Niger River between the first trip of Mungo Park (1795) and the 1841 official British
expedition, looking for the similarities and differences in the representations over time. The
period in question was one of great transformations in the Atlantic context, including the ending
of the slave trade by Britain, and was also marked by a change in the balance of power on the
coast and in the interior of West Africa. This paper therefore aims to show how British ideas
about slavery and the slave trade affected the dynamics of European representation and

* Professor de História da África na Universidade Federal Fluminense (UFF). e-mail: alex_gebara@vm.uff.br 
diplomatic practices towards the societies close to the course of the Niger River. Finally, the article also demonstrates how the almost exclusively geographical concerns of the earlier journeys gradually gave way to an interventionist character of discourse and ownership, while at the same time, the new material and technical conditions led to an imbalance in the power relations, in favor of Britain.

Keywords: English, Niger, slavery, diplomacy.

\section{Brief history of the search for the course of the Niger river.}

In 1788, the Association for Promoting the Discovery of Interior Parts of Africa was founded in London, and as its name suggests, it sought to fill in the 'empty' map of the interior of the continent, and bring information on the trading potential that would eventually open up to Britain. It was also an association with philanthropic ideals, and one that morally questioned the continuity of the Atlantic slave trade, of which Britain was at that time, the biggest agent.

Although the interior of Africa, especially the Sahel, had already been represented by Arabian and North African travelers in the medieval period, legends and ignorance still permeated the European imagery of the region. ${ }^{\text {i }}$

The Association lost no time in focusing its efforts on mapping the course of the Niger River. Before the famous maiden voyage of Mungo Park, in 1795, three other attempts had already been made, by different routes. The first two, in 1788, set off from North Africa and were unsuccessful. John Ledyard, who had traveled with Captain Cook, died before leaving Cairo, and Simon Lucas returned to Britain soon after leaving Tripoli, without achieving anything more than some information about the adjacent region.

The third attempt, in 1790, was made by Daniel Houghton, taking a different route, penetrating the African interior via the Gambia River, at that time a traditional English trading post on the African coast. Houghton never returned, but his name was revived some years later by Mungo Park. He had come close to the Niger, but deviated off the course to the North, where he died at the southern edge of the Sahara.

Seven years after its foundation, therefore, it was Mungo Park, the European, who finally reached the course of the Niger river in the African interior, and returned to tell the tale. Originally following the route taken by Houghton, he had seen "with infinite pleasure the great object of my mission - the long sought for majestic Niger, glittering in the morning sun, as broad 
as the Thames at Westminster, and flowing to the eastwards". (PARK, 1816, 190) However, his task was not completed, as he was unable to map the course of the great river in its entirety. Theories about the hydrography of the interior of the African continent were still wide open. Doubts as to whether the Niger ran toward the Nile, or joined further South to the Congo River, still persisted. ${ }^{\mathrm{ii}}$

Park would return to Africa in 1805 to attempt to complete his work ${ }^{\mathrm{iii}}$ and despite having again reached the course of the river, he met with the same fate as many of the travelers who ventured into the interior of the African continent. In fact, he set off accompanied by "thirty European soldiers, twenty Black servants, fifty donkeys, six horses and six carpenters"; when he reached the river, only seven of the Europeans remained, and when he died in an ambush shortly afterwards, he was the last White man to remain alive (LLOYD, 1973, 52-53).

The search for the solution to the geographical problem in question came to a halt during the wars of Europe, until 1815, and the following year, two other expeditions were launched, one to go down the Niger and the other to go up the Congo, in the hopes of meeting up in the middle. Both failed, again with the deaths of most of the Europeans involved (LLOYD, 1973, 62-65).

The following significant news brought from the interior of the African continent by a European involved in the attempt to map the course of the Niger came as the result of the first voyage of Hugh Clapperton and Dixon Denham, between 1822 and 1824 . $^{\text {iv }}$ Setting out from Tripoli, poorly funded by the British government - Clapperton received one hundred pounds for the trip and Denham offered his services for free - the travelers reached Lake Chad, where they separated. Clapperton headed west, passing Kano and reaching Sokoto, where he came into contact with the Sultan Muhamad Bello. He did not reach the Niger, but received a warm welcome and gathered important information for a subsequent journey, for which he departed just three months after arriving back in England, at the end of 1825.

This time, Clapperton followed with instructions from the British government to establish more definitive relations with Sokoto, setting off from the West coast. Having reached the Niger River, and once again the seat of the Caliphate, he did not survive to tell his tale. His notes and the news of his journey were carried to Europe by his assistant, Richard Lander, who 
also completed Clapperton's account with his own memories. Lander returned by practically the same route as they had taken. And it would be he who, in 1830, would definitively establish the course of the Niger, along with his brother John. The route chosen was similar to that of the previous journey; they left from Badagry and reached the Niger River, sailing towards the coast. ${ }^{\mathrm{v}}$

The general mapping of the course of the Niger River was practically complete, and the 'victory' of British geography opened the doors to a new form of travel. Having demonstrated its navigability, the next attempts to establish contact with the African interior would be by river, sailing up the river in steamships. Perhaps the great name of this new phase of African exploration was McGregor Laird, who was the first to attempt the route, in 1832. In a private enterprise, Laird hired Richard Lander and ordered two steamships - one wooden, the "Quorra", and the other iron, the "Alburkha", the latter being the first iron vessel to sail on open seas - to sail up the course of the Niger. William Allen, then a lieutenant with the British Navy, was appointed to accompany the expedition, and was the only official presence of the British government in this endeavor. At the end of two years, having traveled up the river as far as the junction with the Benue twice, he provided a more detailed mapping of the lower course of the Niger, at a cost of thirty-nine lives of the forty-eight Europeans who had begun the enterprise, Richard Lander being included among the fatalities.

Despite some trade contracts during the 1830s, especially on the part of John Beecroft, future British consul to the Bays of Benin and Biafra, the next major expedition would be the one financed by the British government in 1841, following the plan proposed by Thomas Foxwell Buxton to bring a definitive end to the Atlantic slave traffic. (CURTIN, 1965)

Thus, in around forty years, one of the biggest 'geographical problems' of the 19th century had been resolved, but the question of the high mortality among the Europeans in the region was still a major obstacle to their remaining in the interior. But these years also witnessed major changes, both in the interior of Africa, and in the European relations with the continent. ${ }^{\mathrm{vi}}$

This text therefore seeks to present some of the changes in the representations of Africa, and in the relationship between Europe and Africa in published reports of the journeys described above. It also seeks to reflect, albeit briefly, on the impact of the European presence in the 


\section{The British search for the course of the Niger River: from a geographical problem to potential possession}

interior of the continent on relations between regions.

\section{The European presence}

Direct contacts between Europeans and Africans south of the Sahara Desert go back to at least the 15th century, with the start of the Portuguese voyages in search of a sea route to the Far East. It is certain, however, that much of this prolonged contact was basically due to a specific activity, namely, the slave trade.

Britain, in particular, used West Africa, more specifically the Gold Coast, and the Bays of Benin and Biafra, as the main locations for the establishment of their trading posts. Furthermore, this trade was concentrated mainly in the 18th century. ${ }^{\text {vii }}$

The Atlantic slave trade, however, did not involve European penetration into the continent. This trade functioned through the supply of 'merchandise' directly on the coast, through complex inter-African networks established between different political formations of the interior and the coast. The defense structures of the African States, and the difficulties arising from the high mortality of Europeans in the tropics, did little to encourage the attempts to penetrate the continent which, as we have seen, did not begin until the end of the 18th century. viii

Despite the obvious difficulties encountered by the British travelers in the first half of the 19th century, there was an increasing "naturalization" of the European presence in the societies of the African interior, in the travel accounts. This "naturalization" can be seen at different points in the texts. For example, the constant reference to European goods and products along the routes traveled.

In fact, in the first report of Mungo Park, there is already a clear indication of this presence, when the author states that: "travelers, when they go from Gambia to the interior, pay the tariffs on European goods [...] these rates are paid in every town". (PARK, 1816, 34) Thus, even though he was probably the first 'White' in many of the places he passed through, the 
European presence already existed in the form of goods, which were the preferred 'currency' for the payment of rates on the way to the interior.

Although traveling by a different route, Hugh Clapperton, also supposedly one of the first 'Whites' to enter Kano, was surprised to find a particular item being sold in the market:

For three Spanish dollars, I bought a green English umbrella, an item that I little expected to find, but which is by no means uncommon: my Moorish servants, in their figurative language, were wont to give it the name of 'the cloud'. (DENHAM, 1826, 258)

Although the trade route through which these umbrellas reached the African interior was probably trans-Saharan, their presence here clearly demonstrated a familiarity with at least some types of European goods. ${ }^{\mathrm{ix}}$ A presence that the travelers themselves gradually helped to strengthen - with their increasingly greater loads of 'gifts' to be distributed - and that they, literally, lost no time in emphasizing. Lander, for example, visiting the king of "Katunga", ${ }^{2}$ describing the monarch, reports that:

His robe was a combination of silk and green velvet and red cotton. His feet wore English socks and native sandals, beautifully handcrafted, and underneath was stretched a carpet of fine blue cloth, a present from Captain Clapperton. (LANDER, 1832, 161)

Fabrics and even English socks could be seen in the presentation garb of the king of Oyo. This was not the first time he had been visited by English travelers, and their goods had already been circulating in the region for some time. These references, whether direct or indirect, to the European presence in the interior of the continent, continue to appear in many passages of the account. Perhaps the most interesting of these comes after a brief description of the religious concepts of Yarro, king of Kiama, a seven day walk northwest of Katunga. According to Lander, Yarro called himself a Muslim, but was very unorthodox, given the trust he placed in the tools and symbols of his traditional religion, which were distributed in every corner of his home. In this place, one of the rooms was also adorned with no less than: “(...) very good paintings of our gracious sovereign, George IV, his royal brother, the Duke of York, Lord Nelson, the Duke of 
Wellington on horseback, together with an officer in light-colored uniform, accompanied by a well-dressed and happy English lady". (LANDER, 1832, 206-207)

The nature of this European 'presence' on the continent, however, was changing rapidly, and the relational position between, on one hand the British representatives and on the other, the African authorities and populations, underwent significant shifts in balance during the period covered by the journeys analyzed.

The stated goals of these journeys present an apparent coherence between them. In general, the aims of these journeys were to produce a geographical mapping of the interior, to prospect for new trading possibilities, to spread Christianity and civilization, and to replace the slave trade with so-called legitimate trade. However, these aims alternated in degrees of importance, depending on the period and the traveler. This variation is clear when we compare the texts diachronically.

These nuances of balance in the relationship, as well as the relative importance of the objectives expressed by the travelers, will be explored in the following topics, particularly the accounts of the journeys of Park, Lander, Laird, and the official expedition of 1841.

\section{Mungo Park, or the dependent European}

Park's text begins with the following statement, in the preface:

The following account $[\ldots]$ is offered to the public by the direction of my noble and honorable employers, the members of the African Association. I regret that it is such small reward for the support I received from them. As a composition, it has nothing to recommend it, except the truth. It is a plain, unvarnished account, without pretension of any kind, except that it expands, to some degree, knowledge of African geography. For this purpose, my services were offered, and accepted, by the Association. (PARK, 1816, preface) 
The remainder of the preface is dedicated only to explaining who helped him compile the annotated data, draw the map, and deliver the work for publication. No mention of the slave trade appears at this point.

The first chapter, which begins specifically with the so-called "author's motivations for his journey" and "Instructions and departure", also makes no mention or criticism of the slave trade. His motives are individual curiosity and the certainty of the reward he would receive from the "honorable men" who had commissioned him, if he proved capable of making the "African geography more familiar" to his countrymen, and "opened new sources of wealth and new trade routes for their ambitions and industries". (PARK, 1816, 02) His instructions are limited to the approximate route that should be followed to map the course of the Niger River and establish where it flowed into the sea.

It is important to remember that although funded by the African Association, Park's journey took place more than a decade before the official withdrawal of England from the Atlantic slave trade. And indeed, it would be somewhat ironic to openly defend the extinction of this trade, as the author received goods, guides, even a slave boy to accompany him up the river, from a slave trader named Dr. Langley, established at a trading post miles further inland, on the banks of the Gambia River.

Despite the lack of explicit concern to put an end to the slave trade, Park devoted a chapter exclusively to the institution of slavery in the interior of Africa, concluding with the following passage:

Such are the general outlines of the system of slavery which prevails in Africa; and it is evident, from its nature and extent, that it is a system of no modern date. It probably had its origin in the remote ages of antiquity, before the Mahomedans explored a path across the Desert. How far it is maintained and supported by the slave traffic, which for two hundred years the nations of Europe have carried on with the natives of the Coast, it is neither my province nor in my power to explain. "If my sentiments should be required concerning the effect which the discontinuance of that commerce would produce on the manners of the natives, I should have no hesitating in observing, that in the present unenlightened state of their minds, my opinion is, the effect would neither be so extensive nor beneficial as many wise and worthy persons fondly expect."(PARK, 1816, 290) 


\section{The British search for the course of the Niger River: from a geographical problem to potential possession}

The message in Park's text is relatively clear: slavery in Africa cannot be blamed on the Europeans, or even on the slave trade. And the effects of abolishing the trade would not be significant, as 'many wise and worthy persons fondly expect', in a clear reference to the sponsors of his own journey. Finally, Park seems to maintain a rather negative view of the coeval state of the Africans, i.e. with their "minds in darkness".

The heroic status that Mungo Park acquired, thanks to the completion of his journey and the publication of this book, was due to the fact that he was the first European to have sighted the Niger and returned to tell the tale. Indeed, this was no mean feat in the European imagination, given the high level of mortality among travelers that came before and after Park, as already mentioned. ${ }^{\mathrm{xi}}$

However, the picture that emerges from the reading of the text of his account is more than a kind of anti-hero, destitute, subject to the demands of the African populations and begging for his survival among the slaves in the African interior. The passages in the book where the author is obliged to interact with slaves, in search of something to eat or a place to sleep, are plentiful. ${ }^{\text {xii }}$ These moments appear especially when he is in the Islamic lands, among the Moors, who are portrayed as the great villains in the author's text. According to Park, the concerns with the prospect of "being captured by the Moors and sold as slaves became increasingly apparent" (PARK, 1816, 111)

The following passage clearly shows the place Park occupied in the societies among which he would travel in the months that followed. Having just arrived in "Combe", the author once again became the victim of curiosity and violence of the population:

They gathered around the hut of the Negress where I was staying, and treated me with great insolence: they jeered at me, yelled at me, and abused me: they even spat in my face trying to annoy me and gain a pretext to plunder my belongings. (PARK, 1816, 113)

Far from being an unusual event, the author's submissive condition throughout the 
account constantly appears, in increasingly exemplary form. Being forced to undress and repeat verses of the Koran in Arabic, to eat when and what was offered to him, Park indicates that he had no choice and that he even began to envy the situation of the slaves:

This planned and degrading insolence to which I was constantly exposed was one of the most bitter aspects of this stage of captivity; it often made my life a burden to me. In these stressful moments, I often envied the situation of the slave, who amidst all his calamities, still had the pleasure of his own thoughts; a happiness that, for some time, was denied me. (PARK, 1816, 128)

Faced with this situation, which was highly degrading for a European Christian, being placed in a position worse than slavery itself, the author was completely helpless and could do nothing but comply with every command and patiently endure every insult in return for the hope of keeping his own life. (PARK, 1816, 134)

Although it would be possible, it is not necessary to multiply the examples. The passages above are sufficient to show the inequality of power in the relationship between the European and the African authorities of the interior, especially as he moved further away from the course of the Gambia River, and penetrated the Islamic region of the tributaries of the upper Senegal. On his way back, having failed to fully achieve the objective of the journey to map the course of the Niger River to its mouth, his resignation was still present, and he informed his African interlocutor - and consequently, the European reader - that he was obliged to "go begging for my subsistence, traveling from one place to another, or die of hunger"'(PARK, 1816, 247)

\section{From geography to philanthropy}

The balance of this relationship would be very different in subsequent British forays into neighboring regions. On the journey of Richard Lander and his brother, due to the material conditions in which it was made, they were subjected to some situations in which the Europeans 
could do very little against the African impositions. ${ }^{\text {xiii }}$

Lander and his group were forced, at the beginning of the journey, to sleep outside a town, even though they had walked all day and were completely exhausted. The reason they were not allowed into the town was explained to them: “... the fetish-priest declared that at the moment a White man came into their homes, they would be captured by his enemies and sold as slaves". (LANDER, 1832, 98)

Despite the association between the White presence and slavery, the meaning of which seems very clear to contemporary readers, what is important here is to understand the conditions on which these relations were based. The Europeans were still subject to the decisions of the African powers, even among those with less influence at regional level. ${ }^{\text {xiv }}$ There was no means of imposing any conditions on the Africans.

While not in abject poverty, as had happened with Park decades earlier, the European powerlessness in the interior was still present, as can be seen in the passage in which Richard Lander asked the 'natives' to leave him alone, as his brother was suffering from fever and fatigue.

While my brother was sick, the natives made a hideous noise, singing and banging their drums in a celebration of their fetishes. I went out hoping to persuade them to be quiet, but they just laughed at me and tormented us all the more; because they have no compassion for the suffering of a White man, and if they can humiliate him in any way, they consider this a laudable act. (LANDER, $1832,128-129)$

On this journey, however, the authors alternated between the bad receptions, like the one described above, and a series of more friendly encounters. This is perhaps due to the recurring presence of the travelers in certain places. The route taken by Lander was practically the same as that taken by Clapperton, five years earlier. The same interpreter, a Hausa named Pascoe, accompanied Clapperton and then Lander, through the territory. Richard would also take part in the following trip, that of McGregor Laird, from 1832 to 1834. Also present on this latter trip was William Allen, who captained one of the steamships up the river in the official expedition of 1841.

It was, therefore, a series of reencounters, in which the African chiefs' expectations of the 'gifts' offered by the Europeans, and the recognition of their apparently peaceful objectives, 
may have served to facilitate the passage of the latter groups in the interior of the continent. It appears to be no accident, then, that the greatest difficulties in the journey of the Lander brothers occurred in territory where they were visiting for the first time. ${ }^{\mathrm{xv}}$

With regard to the specific objectives of the journey, the undertaking of the Landers in 1830 was not much different from those that had led to the beginning of the search, forty-two years earlier. The instructions received from the British government, reproduced in the introduction written by British Naval Lieutenant A. B. Becher, indicate that the brothers' work was to complete the mapping of the course of the Niger river that had been partially accomplished by Park and Clapperton on previous journeys. According to the letter: "in short, having once gained the banks of the Quorra, either from Katunga or lower down, you are to follow its course, if possible, to its termination, wherever that may be". (LANDER, 1832, 39)

The introduction itself is the first piece in the process of valorization of the British activity on the coast and in the interior of West Africa. Based on a short history of African geography, returning to the Greek, Roman, and Arab authors before the contemporary period, Becher reports that: "thus, the source of the Niger, as well as its course, remained in obscurity until the British geographers and travelers entered the field. A completely new Era in the progress of African geography had begun". (LANDER, 1832, 28)

This "Era" had begun with the formation of the African Association, according to the author, with the express purpose of promoting discovery in that region. Again, it is important to note the complete absence of reference to slavery and the Atlantic slave trade, among the concerns raised.

These objectives were markedly different in the following accounts. The geographic search was over. The British service on the coast and in the interior of West Africa needed a new rationale. The fight against slavery, which in fact, had already been a British concern since the beginning of the century, now assumed a fundamental role. ${ }^{\text {xi }}$ It was from this moment that the accounts, reports, and proposed plans on the relationship between Britain and Africa started to show, more clearly, the conjunction between legitimate trade and civilization.

In the account of Laird and Oldfield, this appears very explicitly in the dedication to the 
merchants and philanthropists of Great Britain, with the hope that the report would help both: in the opening of new trade channels and the improvement of uncivilized man. (LAIRD; OLDFIELD, 1837) In other words, according to the authors, in addition to vast commercial possibilities, they knew that:

(... ) other and more noble goals were connected to this. By introducing, to the heart of the region, legitimate trade, with all the blessings that go with it, [...] they were dealing a mortal blow to that degrading and demoralizing trafficking that for centuries had cursed that unhappy land and transformed some of the most lovely parts on the face of the globe into the habitation of wild beasts and harmful reptiles, or men in a more degraded and repugnant condition than both. (LAIRD; OLDFIELD, 1837, 03)

Thus, a direct relationship between the slave trade and degeneration is noted, that was completely lacking in the previous accounts. In fact, comparing the statement above with that of Park, at the end of the 18th century, we see a complete reversal of the equation. Although from the beginning, the Africans were presented as "unenlightened", the opinion of Park was that the slave trade had nothing to do with that.

Also significant is the adjective used to describe the Africans in general. While it is difficult to find any positive value in "unenlightened", this qualification is certainly less aggressive than "degraded and repugnant"xvii, or the comparison with "harmful reptiles" or "wild beasts" in the passage above. To use the polished phrase of Patrick Brantlinger, "Africa grew dark as Victorian explorers, missionaries and scientists flooded it with light”. (BRANTLINGER, 1988, 173)

The difference was complete with the culpability of the European countries for the state in which the interior of Africa found itself. ${ }^{\text {xiii }}$ Laird wrote an entire chapter about the evil effects of the slave trade, and even in the manner hitherto used to combat it. This proved to be a key text for understanding the changes in planning for British operations in Africa.

Entitled "Remarks on our Commerce with Africa", the text proposed, according to the author:

(...) briefly to show the importance of the present trade with Africa, the injury 
done to it by the slave-trade, and the increase that might naturally be expected on its extinction; the insufficiency and cruelty of the means at present employed in suppressing it; and to prove that it is in the interest as well as the duty of Great Britain to promote, by all means in her power, the civilization of that country. (LAIRD; OLDFIELD, 1832, 355, v.2)

To argue that the African trade deserved the protection of Britain - not from free competition, but from 'an illegal and brutalizing traffic' -, Laird offers the coeval data of the relationship between Britain and Africa, pointing out the products involved, the structure and functioning, and comparing the total value of the British income with that obtained from trade relations with other European countries, such as Sweden, Denmark, Norway, and Prussia, always to the advantage of African trade. ${ }^{\text {xix }}$

The delay in the loading of the British vessels on the African coast, caused by the constant interruptions caused by the slave traffic, ended up incurring a cost both in financial terms, and in terms of the lives of Europeans. All the arguments presented by the author are accompanied by detailed calculations of the financial loss that the increased costs of insurance and the depreciation caused, for each ton shipped.

To resolve the problem, even knowing that it would not be a definitive solution, Britain should immediately declare slave trade to be like piracy, and keep a cruiser at anchor in each of the ports of embarkation. This is because the form hitherto used to constantly patrol the coasts, without the right to seize vessels that did not carry slaves on board, only increased the suffering of the slaves, and did nothing to stop the trade, due to the relatively low risk for the traffickers. ${ }^{\mathrm{xx}}$

This situation was further morally aggravated by the form of reward offered to the British officers and sailors for the capture of an illegal slave ship, that is, the price per head. This reward, according to the author, was $25 \%$ higher than the actual price of the slave on the market, and did not encourage the suppression of shipments, but rather, the capture of those already loaded. $^{x \mathrm{x}}$ The end of the slave trade alone would increase the population of Africa, encourage work on the land, and improve the living conditions in the interior of the continent. ${ }^{\text {xii }}$ Out of moral duty and commercial interest, Britain was obliged, then, to combat the slave trade and civilize Africa. As this struggle was being done in the wrong way and worsening the conditions of 
the slaves, a plan was needed, particularly, to encourage legal trade.

This project could be executed by installing a belt of British posts in the upper Niger and from the upper Niger to the mouth of the Gambia. This was because both were the only forms of penetration easily achievable by the Europeans, and it had already been shown in practice that maintenance of the coastal establishments alone could not alter the situation.

To those who saw the project as visionary, Laird gave the following explanation:

The reception we have met with, and the freedom which we enjoy, the freedom which we enjoyed from all molestation, sufficiently attest the peaceful and friendly character of the natives. But even if these people are included to oppose the occupation of different points on the banks of the river by our countrymen, they are incapacitated from doing so effectually on account of the disorganized state of the country... (LAIRD; OLDFIELD, 1832, 385-386, v.2)

In this point, the great difference is again noted from the previous accounts, i.e. in the latter, the Africans appear as incapable of opposing the will of Europe. The position of travelers after Lander had little or nothing to do with that of Park, at least textually.

This reversal of the position is not derived solely from the notion of 'reencounters' mentioned above, but also from the form and technology used in these journeys, after that time. The steamship guaranteed a certain safety for Europeans in the relations with the African states on the banks of the Niger River. And here the role of MacGregor Laird's company is notable, in the development of this technology.

While it was not Laird's shipyard that built the ships for his own journey, he would be at the forefront of the technological development of the field in the years that followed. A great enthusiast of steam technology, Laird believed in the possibilities of the British successfully penetrating the African continent, as they held the moral power (religion), the physical power (the adaptability of the 'Anglo-Saxon race'), and the mechanical power needed for this task. The latter derived from:

(...) the legacy of the immortal Watt. By his invention, every river is laid open to us, time and distance are shortened. If his spirit is allowed to witness the success 
of his invention here on earth, I can conceive no application of it that would meet his approbation more than seeing the mighty streams [...] stemmed by hundreds of steam-vessels, carrying the glad tidings of 'peace and good will towards men' in the dark places of the earth which are now filled with cruelty. (LAIRD; OLDFIELD, 1832, 397-398, v.2)

It was Laird's company that was commissioned to build the steamships used in the expedition of 1841. But even more important, it was also he who designed and built the steamship that would become the protagonist of the first opium war, under commission from the East India Company. Launched in 1840, with mobility, speed, and heavy artillery, the Nemesis led a large part of the British victory in the battles. According to Headrick:

With the arrival of the steamships, particularly the Nemesis, Sino-European relations acquired a whole new character. This was no longer the futile confrontation between the whale and the elephant. The steamships brought modern warfare to the heart of modern China. (HEADRICK, 1840, 241)

On board the steamships, European expeditions now had the capacity to threaten any towns and cities within shooting distance of the banks of the Niger, or any other navigable river on the African continent. Perhaps this was the source of Laird's certainty and confidence, rather than the 'disorganized state of the country', despite the high mortality rate that was still afflicting the Europeans in Africa.

The posts in the interior of the continent could, in the author's view, be of two types: commercial trading posts, protected by a garrison, with British officers and African soldiers, or small colonial settlements for agricultural development. The author's preference was for the first alternative, as the second would involve greater costs, with the maintenance of a structure of civil government in those locations. A part of this plan would be clearly taken up again in the plans for the official expedition of 1841 , as we shall see.

\section{The official expedition of 1841: the British guarantee of superiority}


The fight against the Atlantic slave trade was now the main explicit objective that would give legitimacy to the official expedition of 1841 . The ideological basis was the newly released book by Thomas Foxwell Buxton, The African Slave trade and its remedies. (BUXTON, 1840) According to Curtin, Buxton's plan was based on four points: the role of the African squadron in conjunction with the establishment of treaties with African coastal states; government incentive for trade as the key to civilization; the development of agriculture in Africa; and direct exhortation, through religious and moral teaching.

The rhetorical justification for the persistence in attempting to establish a new kind of contact with the interior of the continent, even with the high mortality rate, was based on a moral duty of Europe, as mentioned in the account of Laird, rather than on possible commercial or political interests. ${ }^{\text {xiii }}$ In fact, in the preface of the book by William Allen and Thomas Thompson, dedicated to Prince Albert, president of the Society for the extinction of the slave trade and the civilization of Africa, ${ }^{\text {xiv }}$ the journey was classified as a 'philanthropic undertaking', and the whole history of the attempt to map the Niger came to be explained by the very motive of doing away with the slave trade. According to the authors:

(...) the interest concerning the interior of the African continent lay dormant until the late 18th century, when the fearsome extent reached by the traffic of slaves in Britain sparked an inquiring mind about the countries from where we took thousands of victims each year. (ALLEN; THOMSON, 1848, 07, v. 01)

Now, all the journeys were made on the grounds of slave trafficking, and supposedly, to build tools for its extinction. As it turned out, however, this was not the opinion expressed in Park's text. It was, therefore, a reconstruction of the history of the geographic and commercial search in a philanthropic and moral ideal. This British moral force also appears in the history of the search to discover the African interior, promoting the achievements of the British and showing contempt for others.

As regards the expedition itself, it was completely different from the others. It was heavily funded and supported by the British government, with a series of 'scientists' on board 
(botanist, zoologist, ethnologist, etc.), vessels designed and built specially for the undertaking, and commissioned officers to negotiate anti-trafficking treaties with the African states.

While on the previous journey, the presence of the steamships had guaranteed a relative balance between the Europeans and the Africans in the interior, this time it was recognized and duly valued. Although it was a mission of peace, it needed to have an imposing appearance, according to the authors. (ALLEN; THOMSON, 1848, 31, v. 01)

The situation was therefore very different this time. Armed steamships apparently managed to instill a certain apprehension among the African leaders. In fact, throughout the trip, it was the African kings and chiefs who came on board the vessels to negotiate treaties, not the other way round. ${ }^{\mathrm{xxv}}$

The incursions on land of the Europeans were made only to collect data for their scientific reports, and apparently they faced little or no opposition. In one of the more emblematic cases of this journey, the naturalist on board, returning from an expedition to collect plant specimens, fired at what he thought was a monkey: "there followed a kind of wild shriek, and, running to collect what he believed to be a new species of monkey, he found a black boy, injured in several places from the gunshot, but more frightened than hurt". (ALLEN; THOMSON, 1848, 97, v. 01)

The aggression, unthinkable a decade earlier, was resolved by a small bargain, when the chief "Black Will" had his anger appeased by a small gift consisting of "a cloth and an ax". This passages shows not only the violence involved in collecting material, by the British 'scientists' (FRANEY, 2001, 219-239), but also the ease with which the Europeans managed to circumvent an event that, decades earlier, would likely have resulted in the deaths of some of the members of the group.

This new form of contact, and the scientific pretensions of the report, gave rise to a different Africa, in the eyes of the European readers. Little space was devoted to describing these encounters, the survival strategies, and the construction of routes. Nature and the natives were now 'classified' and organized much more as objects of knowledge than as interlocutors. Much more stereotyped descriptions 'objectified' the natives in terms previously inexistent, such as this 
passage on the "race [...] known to ethnologists as Ibu-Ashanti":

They are generally well-built, muscular, active, and very powerful. Their features are very good, and the chin well-formed; but in some, the feet are rather large and the nose flattened; [...] The head is more oval, and not as high up as their neighbors to the East, the Fantes; and the facial angle favors the former.

(ALLEN; THOMSON, 1848, 124, v. 01) xxvi

Although this descriptive form is not predominant throughout the text, the use of anatomical terms, the reference to the shape of the head, and in particular, the mention of the "facial angle" indicate the start of development of an anthropology that was increasingly based on biological features. ${ }^{x v i i}$ Moreover, the impressions that the text reports on the inferior condition of the Africans in general contrast, somewhat ambiguously, with the assertions of the possibilities of civilizing them, which was the original objective of the journey. ${ }^{\text {xxviii }}$ Furthermore, in a rhetorical movement of 'natural' reinforcement of the European superiority, the Africans themselves appear in the text believing themselves to be inferior; according to the authors "they cannot fail to see that the Europeans, even those of the lowest rank, - involved in the slave trade - are superior in power and wealth", xxix

It is, therefore, with this image of the Africans in mind that we can understand more clearly the texts of the treaties, which in a certain way, perpetuated the 'naturalization' of European superiority. The terms implied a series of responsibilities to be assumed by the African chiefs, and the rights of any British subjects. The Africans undertook to prohibit the transit of slave traders, permit religious freedom in the place, and receive Christian preachers, offering them protection, allowing the British to "cultivate the soil, buy and sell without hindrance" and also to give them protection. They also guaranteed the right of extraterritoriality for any White man, the supply of provisions and fuel, at a fair price, for the British warships, an end to human sacrifices, and a guarantee that the treaties were met, even by their successors. Finally, the British would owe, in exchange, a series of gifts to be offered on the signing of the treaty.

Invariably, the African chiefs and kings agreed in full with the terms; in fact, they

História (São Paulo) v.31, n.2, p. 149-170, Jul/Dec 2012 ISSN 1980-4369 
demanded some guarantee that British ships would regularly visit the local markets, carrying the much sought-after goods, in exchange for palm oil and ivory. ${ }^{\mathrm{xx}}$ The British negotiators themselves, on the other hand, had little faith that the terms would be complied with.

He (the king of Aboh) agreed so readily to everything that several suspicions were raised; first, that he did not understand the proposals; then, that his haste was due to his impatience to receive the gifts that had been promised; finally, we thought it not unlikely that the slave traders on the coast had advised him to comply with all our wishes, and then afterwards do nothing. (ALLEN; THOMSON, 1848, 228, v. 01)

Perhaps this disbelief was derived from the recognition of the draconian terms of the treaty, in exchange for which England would offer no more than a series of "trinkets". In the list of gifts offered we see, for example "a velvet adorned cape, a double-barreled gun, a pair of pistols, thirty-six assorted bead necklaces, a box with scissors, knives and razors, thirty-two small mirrors" among other things. (ALLEN; THOMSON, 1848, 257, v. 01) In another deal that was described, with the king of Idah, the treaty is very similar, as is the list of gifts offered. ${ }^{\text {xxi }}$ But, according to the authors, "it was evident that he was greatly rejoicing over the gifts, which he could hardly buy in exchange for half of his kingdom”. (ALLEN; THOMSON, 1848, 317, v. 01)

The difference in this second treaty was a clause that guaranteed the right of Britain to acquire a territory at the junction of the Niger with the Benue for 'a reasonable price'. ${ }^{\text {xxii }}$ The interesting thing here is that there is a divergence between the British government and T. F. Buxton, concerning the British policy towards Africa. Officially, the government repudiated any territorial acquisition in the interior of the continent, and was even arguing whether it was worth maintaining the existing coastal possessions. (CURTIN, 1965, part 3) Buxton, however, was convinced that territorial ownership and direct rule over certain areas was essential for the process of 'civilization' of the continent. In fact, it was he who wrote directly to John Russell, then minister of the colonies, ${ }^{x x x i i i}$ to argue the issue.

Russells' instructions to the commissioners of the expedition, dated January 30, 1841, 
vehemently emphasized that they should not accept the sovereignty of any territory, even if it were offered free of charge by the African rulers, before first consulting him. Russell wanted only to build small forts and trading posts, as proposed by Laird several years earlier. ${ }^{\text {xxiv }}$

Knowing Russell's position, Buxton wrote to him even before the instructions were written. In a letter dated August 1840, Buxton argued that the main objectives of the expedition namely, to contain the slave traffic and develop agricultural production in Africa - were, in fact, part and parcel of the same movement. Thus, for the agricultural experiments to be successful:

(...) sovereign power (in the place) must be maintained by the British Government, and the natives must obey our laws [...] Our government and our institutions will be pure gain for the Africans. [...] where British sovereignty is firmly established, the civil and religious liberties will prevail instantly, internal conflicts and anarchy will cease. [...] But, if the natives are rulers, we must submit to all their abominations and consent to see human sacrifices, and suffer all the evil influences that such sights exert in all attempts at civilization. (ALLEN; THOMSON, 1848, 433, v. 01)

Russell then informed the commissioners, in a separate letter of instructions, but dated on the same day, January 30, 1841, that based on Buxton's considerations, the British envoys to the Niger could acquire a tract of land of a maximum of one hundred square miles, though not without first reporting to the government on whether the land had a fair price, whether the region was healthy for Europeans, whether the neighboring populations were friendly, and finally, the amount of force needed to guarantee the protection of that territory.

\section{Considerations}

Despite the divergent positions regarding the deployment of territory with British sovereignty in the interior of Africa, we can clearly see a complete change in the pattern of representation of the region in the travel accounts, particularly those made after the journey of 
Richard Lander and his brother.

While in Park, the European appeared almost like a pauper in search of the glory of reaching places as yet unmarked on European maps, and completely subject to the political dynamics of the interior of the content, in the account of Allen and Thompson on the official expedition of 1841, the position was practically reversed, i.e. the Europeans were able to buy 'half' of a kingdom with a handful of trinkets, impose draconian treaties on African chiefs, and ultimately conceive of building a network of colonial establishments under British sovereignty, wherever navigation technology and commercial superiority would permit.

In this process, the African became increasingly portrayed as inferior, the barriers that were previously political and geographical were not limited to the mortality rate due to tropical diseases, ${ }^{\mathrm{xxv}}$ and the empty spaces on the European maps were now filled with names of cities and African populations, as well as the routes of the British 'heroes' who had traveled those parts.

The game of representations was reversed, while the economic and technological developments in Europe increasingly pushed and permitted, respectively, the European presence in the interior. Thus, it seems to be no coincidence that Allen and Thompson, in the first chapter of their book - when referring to the presence prior to that of the British in the interior of the

continent - could now state that they had left no information about our river. ${ }^{x x v i}$ Significantly, the possessive pronoun was written in italics in the original. The Niger and its banks were by this time, at least potentially and textually, British. The journeys, the travelers, and their accounts helped build this potential possession, which as is known, would become a reality within fifty years.

\section{Bibliographic references}

BRATLINGER, P. Rule of Darkness, British Literature and imperialism, 1830-1914. New York: Cornell University Press, 1988. 
The British search for the course of the Niger River: from a geographical problem to potential possession

BUXTON, T. F. The African Slave trade and its remedies. London: John Murray Eds., 1840. Original from 1839.

CURTIN, P. The Image of Africa: British ideas and action, 1780-1850. London, MacMillan \&Co., 1965.

DENHAM, D. CLAPPERTON, H. Narrative of travels and discoveries in Northern and Central Africa, in the years 1822, 1823, 1824. London: John Murray, 1826.

ELTIS, David; BEHRENDT, Stephen; RICHARDSON, David. A participação dos países da Europa e das Américas no tráfico transatlântico de escravos. Afro Ásia, no. 24, 2000.

FORBES, F. Six Month's Service in the African Blockade, from April to October, 1848, in command of Bonneta. London: Richard Bentley, 1849.

FRANEY, L. Ethnographic collecting and travel: blurring boundaries, forming a discipline. In: .Victorian literature and culture. Cambridge: Cambridge University Press, 2001.

GREEN, William. The West Indies and British West African policy in the Nineteenth Century - A corrective Comment. The Journal of African History, vol. 15, no. 2, 1974.

HEADRICK, D. The Tools of Imperialism: Technology and the Expansion of European Colonial Empires in the Nineteenth Century. The Journal of Modern History, vol. 51, no. 2, 1979.

HISKETT, The nineteenth-century Jihads in West Africa. In: FLYNT, E. John (ed.) The Cambridge History of Africa, vol. 5, 1976.

LAIRD, McGregor e OLDFIELD, R. A. K. Narrative of an Expedition into the Interior of Africa, by the River Niger, in the Steam-Vessels Quorra and Alburkah, in 1832, 1833, 1834. London: Richard Bentley, 1837.

LANDER, R., LANDER, J. Journal of an expedition to explore the course and termination of the Niger: with a narrative of a voyage down that river to its termination. New York: J. Harper, 1832.

LAW, Robin. Robin Law: The Oyo empire c. 1600-c. 1836: A West African imperialism in 
the era of the Atlantic slave trade. (Oxford Studies in African Affairs) XIV. Oxford: Clarendon Press, 1977.

LLOYD, Christopher. The Search for the Niger. London: Redwook Burn Limited, 1973.

LOCKHART, J. B. and LOVEJOY, P. Hugh Clapperton into the Interior of Africa. Records of the Second Expedition 1825-1827. Brill Academic Publishers, 2005.

OGUNTOMISIN, G. O. Political Change and Adaptation in Yorubaland in the Nineteenth Century. Canadian Journal of African Studies, vol. 15, no. 2, 1981, pp. 223-237.

PARK, Mungo. Travels to interior districts of Africa: performed in the years of 1795, 1796 and 1797, with an account of the subsequent mission to that country in 1805. London: John Murray, 1816

RICHARDSON, R. The Story of the Niger, London: Thomas Nelson and Sons, 1888.

SINCLAIR, William. The African Association of 1788. Journal of the Royal African Society, vol. 1 , no. $1,1901$.

STOCKING, G. Victorian Anthropology. New York: The Free Press, 1987.

TAX, Sol. The settings of the Science of Man. Horizons of Anthropology. Chicago: Albine, 1964

\section{Notes}

\footnotetext{
i Also at the end of the 18th century, Timbuktu could be portrayed as a true Eldorado in the interior of the continent, where 'gold was so abundant that it even the slaves were adorned with it". And according to the same author, Sir John Sinclair, founding member of the Africa Association, "If we can manage to take our goods to that country, we will soon have enough gold". SINCLAIR, William. The African Association of 1788. Journal of the Royal African Society, vol. 1, no. 1, 1901. My translation, like the other quotations from the text originally in English.

ii As is known, none of the alternatives imagined by the English geography of the time proved to be true.

iii Prior to that, no less than three other attempts had been made, financed by the African Association, and all of them resulting in the traveler's death. See RICHARDSON, R. The Story of the Niger. London: Thomas Nelson and Sons, 1888 .

iv In fact, other expeditions took place around the same time. Gordon Laing set off before Clapperton's return, with the aim of reaching Timbuktu from the North. Having achieved his objective, he died en route to the Niger. And
}

História (São Paulo) v.31, n.2, p. 146-170, Jul/Dec 2012 ISSN 1980-4369 
Renè Caillié, leaving Senegal in 1827, reached Timbuktu and headed north, supposedly pretending to be a Muslim. v Not without great irony, as apparently, Lander was 'enslaved' and sent down river to be sold. See Lockhart, J. B. and Lovejoy, P. Hugh Clapperton into the Interior of Africa. Records of the Second Expedition 1825-1827. According to the authors: "In fact, the Lander brothers were attacked by pirates near Onitsha, and sold down river to an Ibo official in Aboh [...] they were rescued by Captain Lake and taken back to England.”, p 2.

vi The journeys took place in the period of formation of the Caliphate of Sokoto after the Jihad, begun in 1804 by Usuman dan Fodio, the collapse of the so-called Oyo Empire, in the Yoruba region, and therefore, a period of constant wars between the African regional powers. On the Yoruba wars, see for example: Oguntomisin, G. O., "Political Change and Adaptation in Yorubaland in the Nineteenth Century". Canadian Journal of African Studies, vol. 15, no. 2, 1981, pp. 223-237. For an approach on the Oyo empire, see Law, Robin.Robin Law: The Oyo empire c. 1600-c. 1836: A West African imperialism in the era of the Atlantic slave trade. (Oxford Studies in African Affairs) XIV, 340 pp., Oxford: Clarendon Press, 1977. And for the formation of the Caliphate, see Hiskett, "The nineteenthcentury Jihads in West Africa" in: Flynt, E. John (ed.) The Cambridge History of Africa, vol. 5.

vii The numbers of slaves shipped to Britain from these locations is given at http://slavevoyages.org/tast/database/search.faces?yearFrom $=1514 \&$ yearTo $=1866 \&$ mjbyptimp $=60400.60500 .60600$ \&natinimp $=7$. For a consideration on the volume of slaves trafficked by Britain, see: Eltis, David; Behrendt, Stephen; and Richardson, David. "A participação dos países da Europa e das Américas no tráfico transatlântico de escravos”, Afro Ásia, no. 24, 2000.

viii With the exception of the relationship between Portugal and West Central Africa, where colonies were established in the 16th century, the attempts to penetrate and gain political control of the interior were constant. Despite this, however, only a small territorial space was formally in the hands of the Portuguese State at the beginning of the 19th century.

ix Umbrellas are also symbolic elements of power in much of the African interior. There are numerous mentions of reports of journeys to African chiefs sitting under their umbrellas at official events.

$x$ Katunga is the Hausa name of the Old Oyo capital

xi According to Curtin, the annual mortality rate among British military personnel in Sierra Leone between 1817 and 1836 was $48.3 \%$, and on the Gold Coast, $66.83 \%$. Compare this with $1.53 \%$ in Britain itself. Apud. Headrick, D. "The Tools of Imperialism: Technology and the Expansion of European Colonial Empires in the Nineteenth Century", The Journal of Modern History, vol. 51, no. 2, 1979.

xii By way of example, the passage in which Park is fed by the benevolence of an old female slave, at the start of the journey, is mentioned. Park, M. Travels to interior districts..., p. 67, vol. 1. On this occasion, he was begging for provisions.

xiii In fact, although in the publication the editors seek to value the involvement of the British government in the execution of what was at that time a great step for geographic science, it is clear that the interest and financing for the expedition were not readily forthcoming. Only small amounts of funds were released for the journey. John Lander traveled without any pay. The expedition set sail for Africa in a merchant vessel, and it was only when they reached the African coast that they were transferred to a British naval cruiser, which dropped them at Badagry. Lander, J. and Lander R., Journal of an Expedition..,. preface.

xiv The prohibition on entry gave rise to a small village called "Latoo", in the area close to Badagry.

$x v$ The above mentioned capture in Onitsha (Kirree in the account).

xvi On the British squadron in the fight against slavery, see Curtin, P., op. cit. It is also worth nothing that after the end of the war in Europe, in 1815, Britain began to form treaties with other European States, seeking to end slavery.

História (São Paulo) v.31, n.2, p. 149-170, Jul/Dec 2012 ISSN 1980-4369 
Portugal and Spain, for example, signed treaties to this end, in 1818.

xvii Disgusting and degraded in the original

xviii "For centuries, we have been the means of destroying life to a frightening extent, - of desolating whole districts, of annihilating all the domestic relations [...] We have debased and degraded them to the level of animals, and taunted them with mental incapacity. [...] We have abused them for idleness while fattening upon their labor". Laird, McGregor and Oldfield, R. A. K., Narrative of an Expedition..., p. 377, vol. 2

xix Although, perhaps for the good of his argument, he did not wish to compare very different things, i.e. European countries with a small share of the European foreign trade, on one hand, with large swathes of land in Africa, on the other.

Xx A similar argument would be taken up again by various British agents on the West Coast, in subsequent decades. See, for example, Forbes, F. Six Month's Service in the African Blockade, from April to October, 1848, in command of Bonneta, London: Richard Bentley, 1849. Moreover, according to Laird, although the slave trade could only change location, the ports monitored would decrease the losses and delays in shipments with legal merchandise in British vessels.

xxi Four pounds per slave bought on the market, and five pounds for the delivery of the recaptured slave in Sierra Leone.

xxii Despite the overwhelmingly negative portrayal of the Africans, these were not the lazy, irredeemable people that might have been supposed, the demand for important products would be sufficient to make him work. In other words, the blame truly rested on the slave trade.

xxiii According to Green, however, the motive of the British interest in doing away with the slave trade had more to do with protecting sugar production from the East Indies, supposedly based on free labor since 1833, than with the crisis of morality of the British philanthropists. See: Green, William. "The West Indies and British West African policy in the Nineteenth Century - A corrective Comment", The Journal of African History, vol. 15, no. 2, 1974, pp. 247-259

xxiv The difference in nomenclature of this recently-created society from that of the African Association for the discovery of interior parts of Africa is observed.

xxv A notable exception was king Attah, of Idah.

xxvi Another, similar description of the Fantes can be seen on page p. 155 of vol. 1, though this one is much more negative than the first.

xxvii For the shift of paradigms in British anthropology between 1840 and 1870, see, among other texts: Tax, Sol. "The settings of the Science of Man". Horizons of Anthropology, Chicago: Albine, 1964 and Stocking, Victorian Anthropology, New York: The Free Press, 1987.

xxviii Mentions of failure in the attempts to 'civilize' the Africans are thus far quite numerous in the text, the blame generally being placed on the laziness and aversion to work of the majority of the Africans. See, for example, p. 84, $85,134,144$, and 156 , among others.

xxix The supposed desire of the Africans themselves for the European guardianship came to be a constant theme of the colonial rhetoric, decades later.

xxx The negotiations are described in detail in the text itself, and the treaties are given in full as an annex to the book.

xxxi The list, in this case, is a little longer, but contains basically the same items. Allen, William and Thomson, T. R. H., A narrative of the expedition..., pp. 315-316, vol. 1.

História (São Paulo) v.31, n.2, p. 146-170, Jul/Dec 2012 ISSN 1980-4369 
xxxii Now, if the price of 'half of the kingdom' was the content of the presents already offered for the signing of the treaty, we can imagine how much the 'fair' price for the desired piece of land must have been.

xxxiii Secretary of State for War and the Colonies.

xxxiv As clearly appears in article 25 of Russel's instructions to the commissioners, reproduced in Allen, William and Thomson, T. R. H., A narrative of the expedition..., pp. 421-422, vol. 1.

xxxv But not for much longer, in fact. In 1857, William Baikie made a journey to the confluence of the Benue and the Niger, without the deaths of any of the Europeans involved.

xxxvi Allen, William and Thomson T. R. H., A narrative of the expedition... p. 6

Received in October, 2012.

Approved in November,2012. 